Journal of World Englishes and Educational Practices (JWEEP)

ISSN: 2707-7586

DOI: 10.32996/jweep

Website: https://al-kindipublisher.com/index.php/jweep/index

\title{
Complex Deictic Centers, Projections and Context Deictic Centers in Al-Araff Verse
}

Bushra W. Ali

Department of Statistics, University of Sumer, Alrifaee, Iraq

Corresponding Author: Bushra W. Ali, E-mail: mrsouda1978@gmail.com

\begin{tabular}{ll}
\hline ARTICLE INFORMATION ABSTRACT
\end{tabular}

Received: September 12, 2020

Accepted: October 16, 2020

Volume: 2

Issue: 5

DOI: 10.32996/jweep.2020.2.5.3

\section{KEYWORDS}

Deixis, Deictic Projection, Deictic

Context and Complex Deixis
The study examines the deixis in the Al-Araff verse selected from the Holy Quran, especially the complex as a new type of deixis. The content analysis of deixis is time, place, person deictic centers, context, and deictic projections. The results show that we can guess a new type of deixis which is the complex deictic center of person because so many words in Arabic language are able to hold two references for two words, this is in complex word that can be named as complex deixis. Moreover, time and person deictic centers become a deictic projection at some places, and we have place and time deictic centers which are context deixis that can be predicted by the general atmosphere. The deictic centers of place are divided into high and low deictic centers. Also, the deictic centers of time are divided into beginning and end deictic centers. The person deictic center is divided into good and bad deictic centers. Using Levinson's ideas and divisions about deictic center can be presented in this sense.

\section{Introduction}

Holy Quran communicates with the readers through different linguistic forms by expressing the meaning of the context in the Quranic discourse. Deixis is one of them. The benefit of deictic forms lies in the fact that the Quran's basic function lets readers know the creation fact and the message of the devil's indocile to devilish a man as an evidence for God existence. That honest creature can be a devil too, just like Ebleas. This is clearly guessed by the deictic projection. But, God gives His word that earth is for good man. The war started since the creation of man till the rescuer time who will secure all mankind. In this context, we should know a brief idea about deixis. It is commonly known as an aspect of language that requires a reference. Deixis are divided into person deixis, place deixis, and time deixis. This is according to Levinson's (1997) thought of deictic centers, but, the study limits on complex, context, projections and what we have biked by Livenson's deictic types of person, time and place deixis centers. Then, the researcher tries his best to find out the types for each one by the verses' analysis of Al-Araff Quran verse.

\section{Literature Review}

What do we mean by the linguistic term deixis? It can be defined as a phenomenon that can be managed to recognize the meaning of words or phrases using the contextual meaning. Deixis is a word which can take some kinds of its meaning from the utterance which is used by the speakers (1997) for example نانا (هان الكم فيها معايش قليلا ما تشكرون refers to a good person قليلا deictic word refers to a bad person. All these references help the reader to identify the meaning by context.

Linguistically, Lyons (1977) states that the term "deixis" comes from Greek word means (indicating) which is used in linguistics to indicate the function of pronouns, tenses, and other lexical and grammatical features. Lyons adds; deixis means the identification of activity, person, object, and event. These can be talked about relating context, that specified by the speech act and the applicant.

K C AL-KINDI CENTER

R D FOR RESEARCH AND DEVELOPMENT Your gateway to world-class research
Published by Al-KindiCenter for Research and Development. Copyright (c) the author(s). This is an open access article under CC BY license (https://creativecommons.org/licenses/by/4.0/) 
Levinson (1997) thinks that semantic and pragmatic interpretations of deictic expressions are fixed to particular points in the communicative occasion. These anchorage points constitutes the deictic centers: (1) the central person is the speaker (2) the central time at which the speaker produces the speech (3) the central place at which the utterance location (4) discourse center which is the fact at which the utterer is presently at in speaking time (5) the social center which the social statue and rank of the speaker. Moreover, there are various derivative usages of deixis according to Levinson, that are used in a certain way that shifts the deictic center, this is called by Lyons as deictic projection.

Deictic analysis in the research is made by M. Zaini Miflah (2016) in which he studies the deixis in the Jakarta Post. He uses content analysis to find out the kinds of deixis, which can be found in the Jakarta post. He finds the person, special and temporal deixis. The deictic words are (third person singular pronoun) "it, l, me, we," which are the first person singular pronouns , "your" as possessive form of pronoun "you." and the possessive form of the pronoun "he" which is "his." Special deixis are (that and here) while temporal deixis are (now and this year).

Shazali (2011) made a study to comprehend academically oriented aspects of deixis, which can help to reconcile between structural syllabus and notional syllabus. In this study, the writer tries to find out a common frame of deixis usage in pragmatics as an interpretation. It is an item in the materials of writing reflects how learning skill is affected. Also, it shows the way teachers and learners interact with each other by this curriculum, moreover, how these materials have improved to solve problems. The study finds out that it would be beneficial for the designer of the English syllabus.

Finally, Pratiwi (2018) limits his study to person deixis, in which he categorizes the kinds of person deixis in the book of AsAalat, which is translated by Dr. Muhammad Muhsin Khan. In this research, he uses Levinson's outline of deixis to person deixis. Moreover, he found out the dominant deixis is third person singular in (he).

\section{Methodology}

According to Levinson's semantic and pragmatic interpretations, deictic expressions are fixed to particular points in the communicative occasion. These anchorage points constitutes the deictic center : (1) the central person is the speaker (2)the central time at which the utter produces the speech (3) the central place at which the utterance location (4) discourse center which is the point at which the speaker is currently at speaking time (5) the social center which is the social statue and rank of speaker (Levinson,1997) for the limitation purposes we deal with the first three centers of Levinson. Moreover, the deictic centers are divided into types; place center is divided into high and low deictic center. Time center is divided into beginning and end deictic center, whereas a person center is divided into good and bad center deixis.

The first verse contains all types of deictic centers.

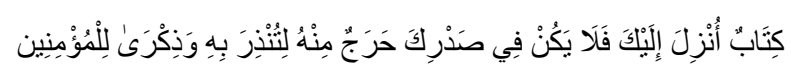

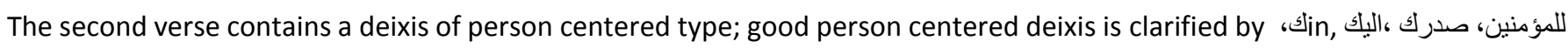
and the absent person pronoun on the word لتنذر انزل is a deictic center for good person center which is the representation of the Almighty God. Time deictic center actually is a deictic projection between the starting and ending centers. While, the low place deictic center lies in the general context of verse, which is the deictic context.

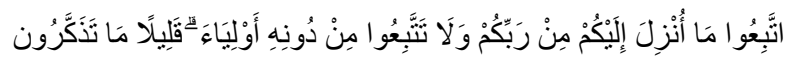

The third verse deixis of good person center is represented by the Almighty God's order to follow the book., which lies in the

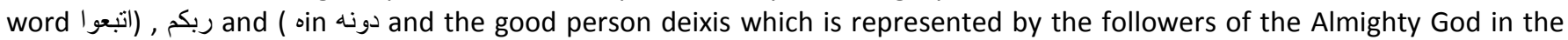

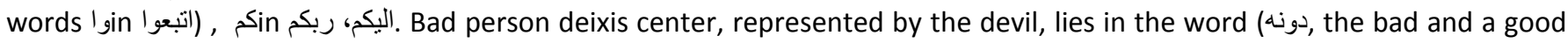

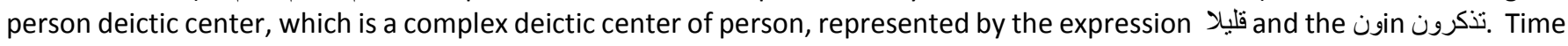
and place deictic centers are clearly guessed by the context of verse. Time is deictic projection; while a place deictic center is low.

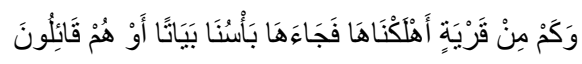

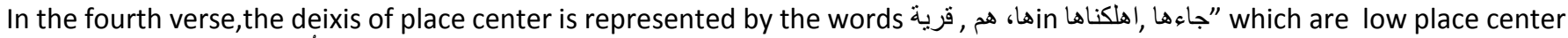
type, this word هم رية قَائلُونَ itself is a center for both bad and good person, which is a complex deictic center of person, because this expression (the village) contains bad and good persons together. The deixis of time center appears clearly in باتانا قائلون; we guess the meaning of night time by the end deictic centered word بياتا. Also, we can guess the meaning of noon time 
by the word قائلون because the people have a short time to sleep at noon time. Finally, we guess low place deictic context in the verse.

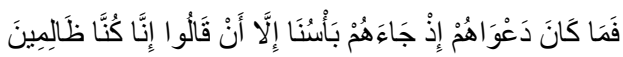

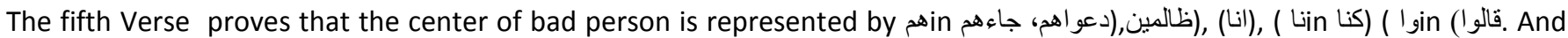

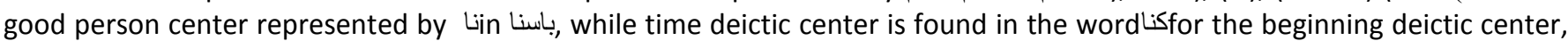
and كان for end time center. Finally, we guess low place deictic context in the verse.

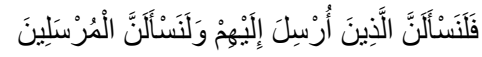

The sixth Verse of good person deictic center is represented by المرسلين, the absent object for the verbلرسل . This word represents the absent object of the passive verb as a clue for a good person center which is God, this center is found in ، فالنسالن الن , the person deictic center is found in النهم (النسالن, Time deictic center is found in the context and the atmosphere of the verse, type end time deictic center, this is context deictic center.

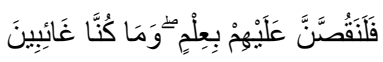

The seventh Verse contains the good person deictic center that lies in the absent pronoun of فالنقصن representation of the Almighty God. Also, we can guess that the good person deictic center lies in the word عin .The seventh verse contains a good person deictic center in the words غائبين، center exist on the verse's context. The high place deictic center lies in the verse context, and the end time deictic center lies in the verse context which is the deictic context.

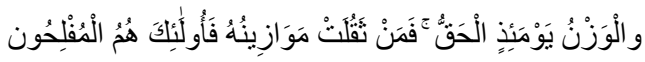

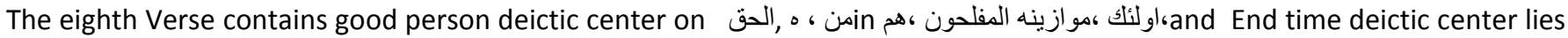
in the word يومئذ, high place deictic center actually is the deictic context of high place.

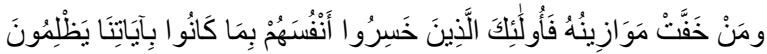

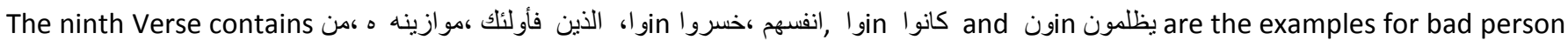
deictic centers in this verse, good person deictic centers lies in the word بآياتنا فin نnd time deictic center lies in the context of verse, this is the deictic context.

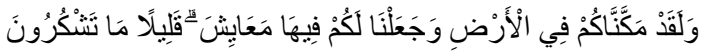

The tenth verse contains the deixis of low place center, which lies in the word فئها انها الارض. While deixis of good person center

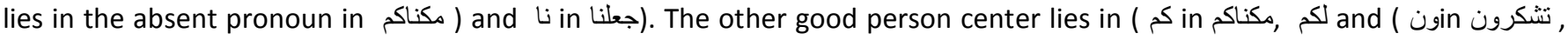
while the bad and good person deictic center lies in the word قليلا. Here, we have the complex deictic of person is both of good and bad person deictic centers. Whereas, the time deictic center lies in the context and the atmosphere of verse, this is the deictic context which is a projection between end and begin time deictic centers.

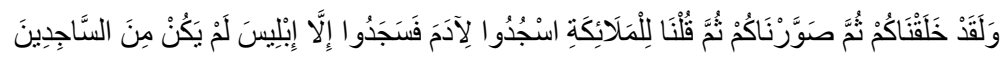

The eleventh Verse ,the deictic center of person which is a good person type lies in Adam's generations of people. This is

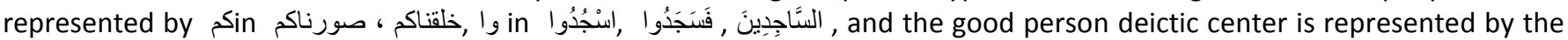

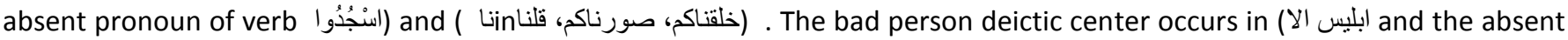
pronoun in the verb يكن. The beginning time deictic center lies in the context and atmosphere of verse, this is the deictic context

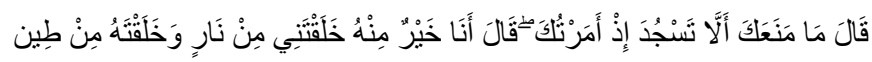

In the twelfth Verse, we have the deictic beginning time center, which is the creation time, and the time that Ebleas made his sins which can be a guess by the deictic context of verse. The good person deictic center is found in the absent pronoun of

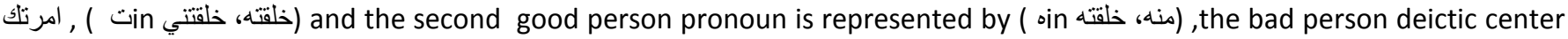

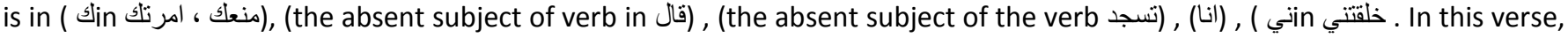
we have a balance between good and bad deictic centers, because we have a clear comparison.

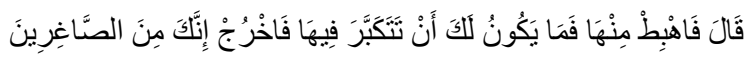


Thirteenth deictic center of the place is the high place deictic center appears in the word (هيطها) (هيطا) and it is a place of high qualities appears by the word تتكبر) and this high place is the place for good persons which is clearly clarified by (الصاضرين and because satan is bad person deictic center so this high place is not for such a kind of persons. Also in this verse the deictic

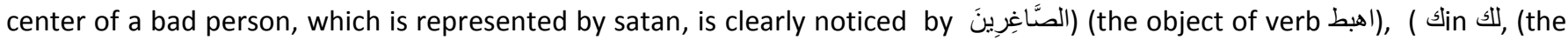

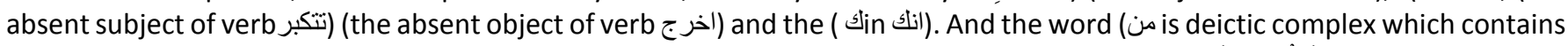

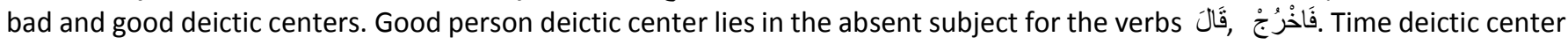
lies in the context, which is a begin time deictic context center.

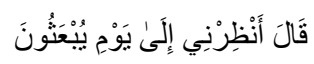

In verse number fourteen, there are two types of deictic centers, time and person. Time deictic center is of end time deictic center type, which is (doomsday) that lies in the fact that we find the expression of يوم يبعثون, also, we guess the begin time deictic center lies in the fact of word أَنْظِرْنِي. While, the deictic center of person is of bad person deictic center type represented

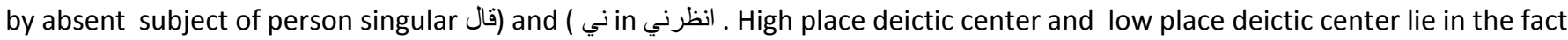
that ( انظرني to give satan space of time not to go to the lower place right now and remain in the high place, this is a complex deictic center of place. Therefore, we can guess the high place deictic center and lower place deictic center as well.

فَالَ إِنَّكَ مِنَ الْنْنْرَرِينَ

The fifteenth deixis, is represented by the good person deictic center, which lies in the expression of absent pronoun for the

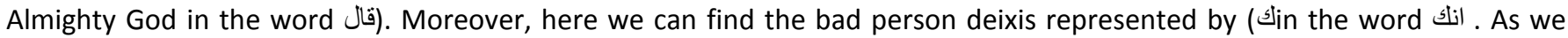
noticed in the previous verse, we can guess a complex deixis of both good and bad person lies in the fact of 2 ).Also, the high place center, where the devil asked for a space of time, which is between begin and end type, represents the deictic projection represented by the word الْمُنْظَرِينَ

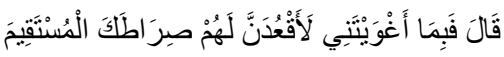

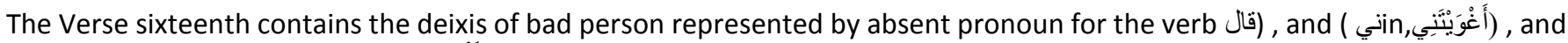

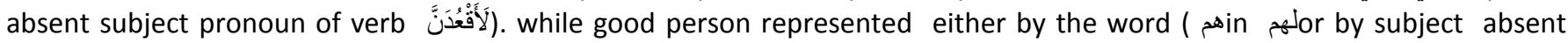

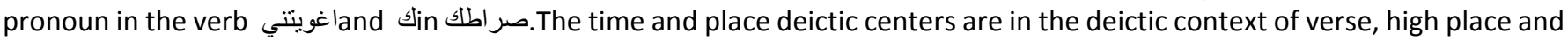
begin time deictic centers.

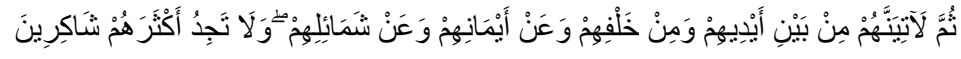

The seventeenth Verse contains bad person deictic center lies in the absent pronoun of لاتينهم : Another person deictic center is

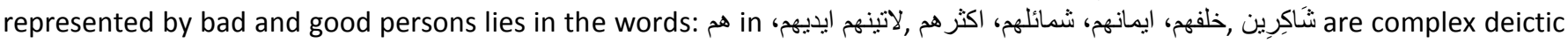
centers. and the object of verb لا لا تجد () شاكرين (is good person deictic center and the good person deictic center in this situation we can see the deictic center of bad person which is satan who tries to make it's revenge to change the deictic center of good person to be a deictic center of bad person, this is the climax of deictic projection. The time deictic center in this verse is between the beginning and end of deictic center types, that can be guessed by the deictic context of time and place.

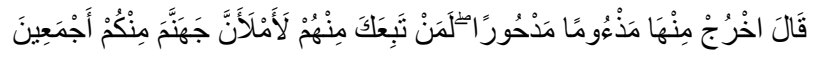

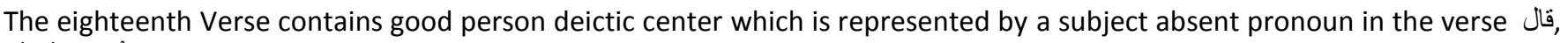
اخرج) (اخرُجْ ،لأملأن and تبعك in is is for satan. Also, we have the deictic center of a bad person which is represented by the

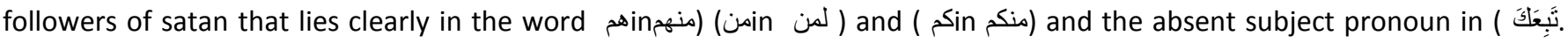

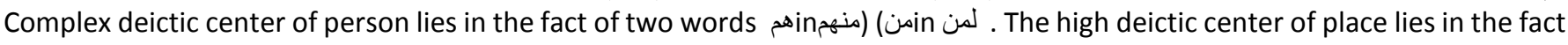
that the word sis, which refers to the paradise where satan is given a space of time after it's sin. Here we can see low deictic center of place which is the place of penalty lies in جهن, where the devil and it's followers face the same penalty out of their sin, also, by the verse context we guess the begin time deictic center, the utter occurred at the high place. This is can be predicted by اخرج to go to lower place deictic center .

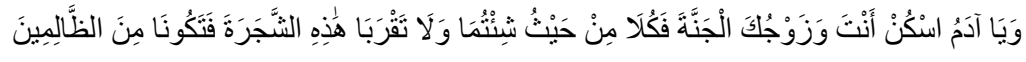

In the nineteenth Verse,the deictic center of good person referred by the speaker is the Almighty God. This is the good person

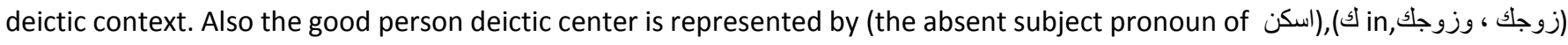

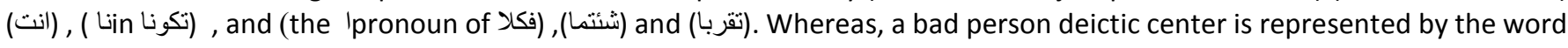


(الظالمين) However, high place deictic center is represented by the word الجنة) and we have another referent for high place by (اسكن in which the verb is high place center. Moreover, we guess a complex deictic center of person lies in the word من Deictic context of begin time center is clearly guessed by the general atmosphere of verse.

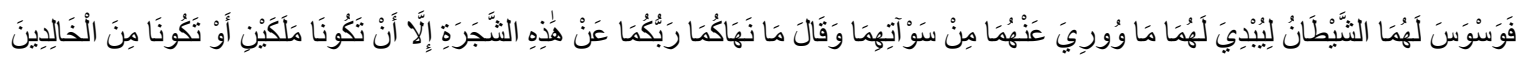

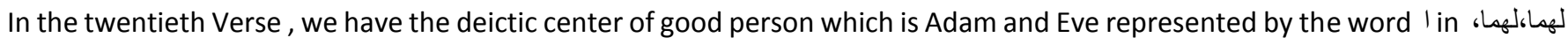

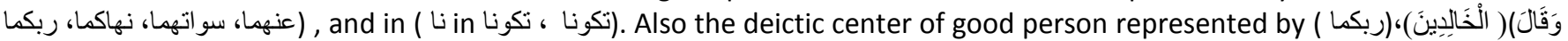
and the absent subject pronoun of verb ووري، نهاكما In this context, the deictic center of good person is about to be a deictic center of bad person because, Adam an Eve follow satan this is the revenge of satan to make Adam and Eve sinners like him, this is to improve that he is not the only sinner, and even the good person who all the creatures bend to him can be a sinner( bad person deictic center) like him. Here we have the deictic projection. Also, we guess a complex deictic center of person lies in the word (من). And bad person deictic center appears in the fact that we have the absent pronoun of subject in the verb

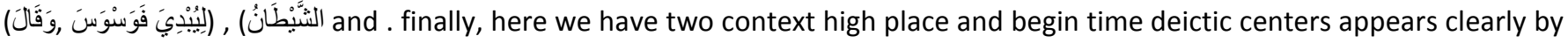
context of verse.

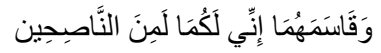

In the twenty-first Verse, the continuity of the deictic projection of good person and bad person deictic center shifts in Lهin

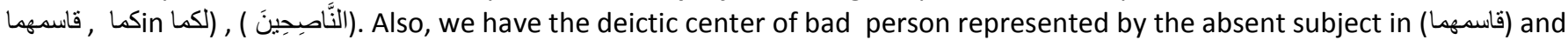
this is satan which is the bad person deictic center. Finally, we have the complex deictic center of person in من At this point, we have two context, high place and begin time deictic centers that appears clearly in the context of verse.

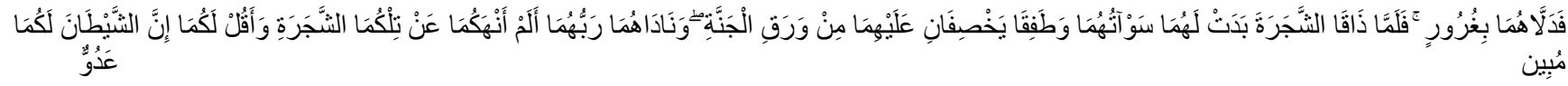

In the twenty-second Verse, the continuity of deictic projection in which the shift of good person deictic center to bad person

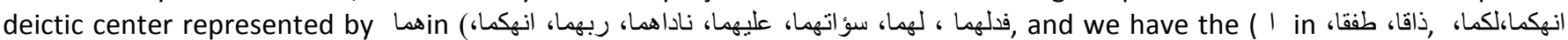
تلكما،لكما, (the absent object pronoun in . (يخصفان،), the deictic center of bad person which is represented by satan, the word

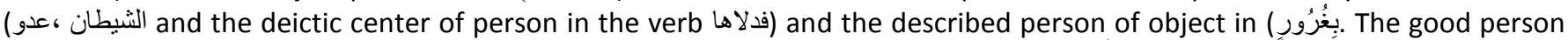

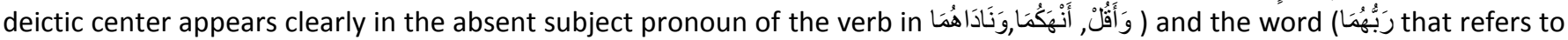
the Almighty God. We have context of begin time deictic centers appears clearly by context of verse.

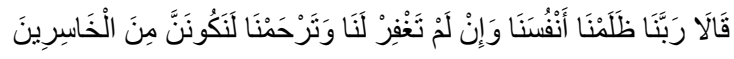

In the twenty-third verse, the release of deictic projection climax lies in this verse. The bad person deixis shift to good person

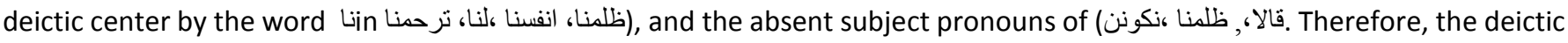
center of good person can be changed and shift to be a deictic center of bad person because of satan's inducer, to satisfy his revenge when the Almighty God requests to bend to Adam. The clear good person deictic center is in the word (رب) and the absent subject pronoun of (تغفر. Bad person deictic center appears in the word الَْاسبِِينَ. The place is high place deictic center is known by the deictic context

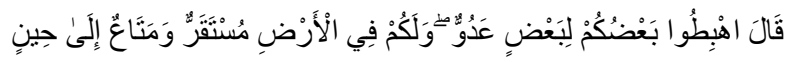

In the twenty-fourthVerse, deictic center of good person lies in (the absent subject pronoun of قال And deictic center of bad

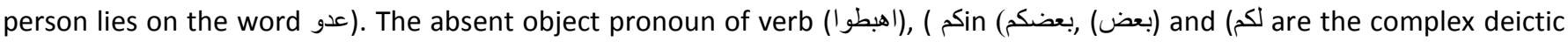
centers of person. Also, we have the deictic center of high place in الهبطو الارض) (الارض) Deictic the deictic center of lower place center of end time exists in this verse, and can be noticed by the word حيط. Finally, the place deictic projection lies in the fact of words

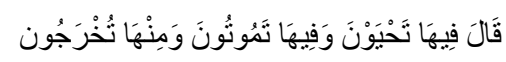

The twenty fifth Verse contains a deictic center of good person which is represented by the absent subject pronoun of قال which

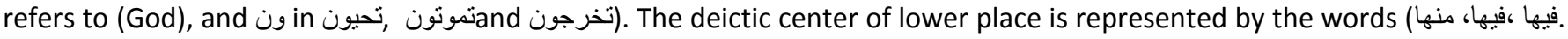
And the deictic center of time represented by the continuity and the sequence of actions of تحيون، تمونون، تخرجون that describe deictic projection.

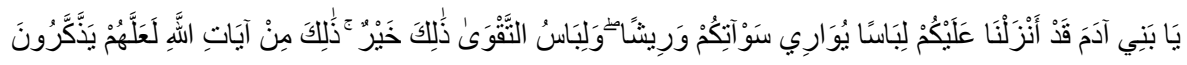




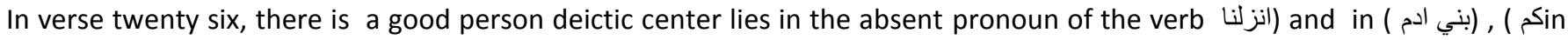

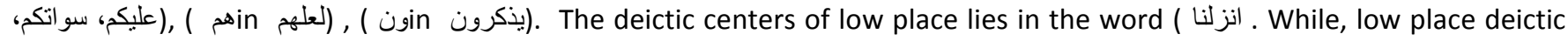
center appears clearly by context of verse

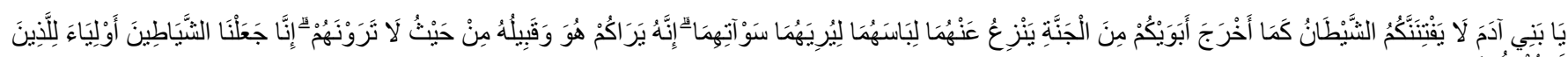

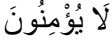

In the Twenty-seventh verse, the deictic center of good person can be represented in two positions: the first position lies in

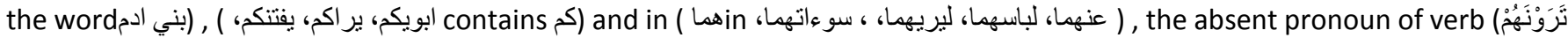

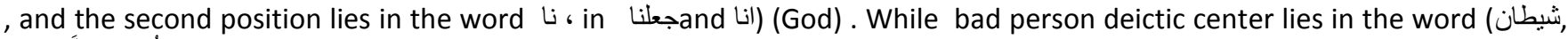

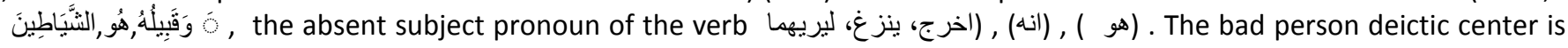

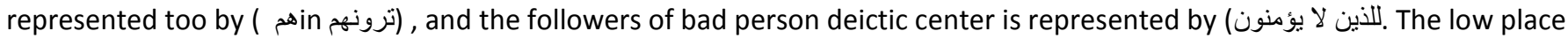
deictic center can be known by the general atmosphere which is the deictic context of low place, while the high place deictic center is represented by the word (الجنة. The time deictic center that can be guessed by the general atmosphere is the deictic context of time, which is deictic projection.

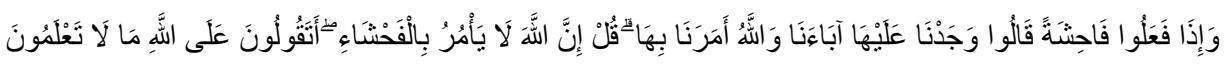

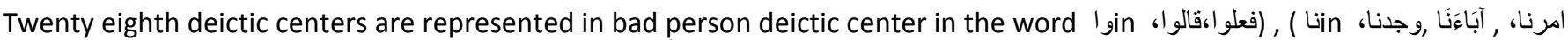

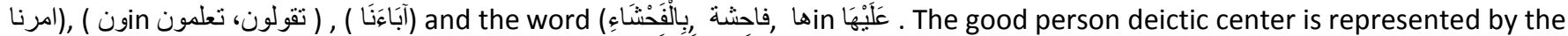

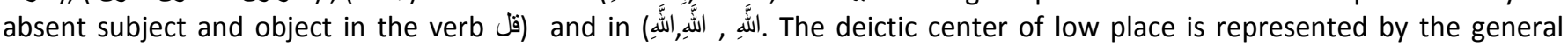
atmosphere and the context deictic center of place, which is deictic projection.

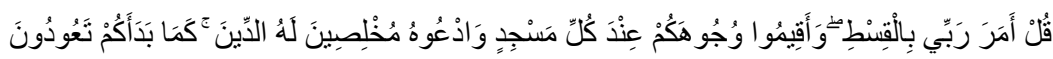

In the wenty ninth verse, the good person deictic center is represented by the absent of subject and object in the verb (قل),(

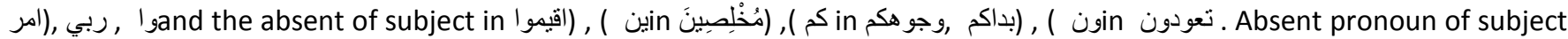

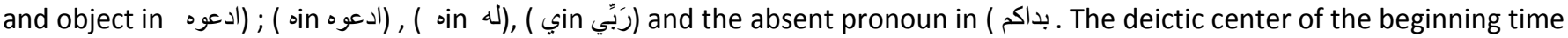
is represented by the word (بداكم) (تعود). Whereas, the place deictic center of low place by the general atmosphere is the context deictic center of place.

\section{Results}

In this research we find out;

Table (2) shows projection's scores emphasizing the following points; person projection scores (6), the highest, time scores (5) point and the lowest projection is for place which scores (1) point only.

Table number (3) shows that Context deictic center results prove that place scores the highest points which is (17) followed by time context deictic center which contains (16) point. Whereas, the lowest context deictic center is for person which scores (1) point only.

\section{Table (1) Deixis and Complex Deixis}

\begin{tabular}{|c|l|l|l|l|l|l|l|l|l|}
\hline V no. & \multicolumn{2}{l}{$\begin{array}{l}\text { Person deictic } \\
\text { center }\end{array}$} & \multicolumn{2}{l}{$\begin{array}{l}\text { Place deictic } \\
\text { center }\end{array}$} & \multicolumn{2}{l|}{ Time deictic center } & \multicolumn{2}{l|}{ Complex deixis } \\
\cline { 2 - 10 } & good & bad & high & low & begin & End & Person & place & Time \\
\hline 1. & 1 & 1 & 1 & 1 & 1 & 1 & 1 & 1 & 1 \\
\hline 2. & 5 & & & 1 & & & & & \\
\hline 3. & 10 & 2 & & 1 & & & 1 & & \\
\hline 4. & 10 & 1 & & 4 & & & 5 & & \\
\hline 5. & 1 & 6 & & & 1 & 1 & & & \\
\hline 6. & 6 & & & & & 1 & & & \\
\hline
\end{tabular}




\begin{tabular}{|c|c|c|c|c|c|c|c|c|c|}
\hline 7. & 5 & & 1 & & & 1 & & & \\
\hline 8. & 6 & & 1 & & & 1 & & & \\
\hline 9. & 1 & 6 & & & & 1 & & & \\
\hline 10. & 4 & 4 & & 2 & & & 1 & & \\
\hline 11. & 9 & 6 & & & 1 & & & & \\
\hline 12. & 6 & 6 & & & 1 & & & & \\
\hline 13. & 3 & 7 & 5 & & 1 & & 1 & & \\
\hline 14. & & 2 & & & & & 1 & & \\
\hline 15. & 2 & 2 & & & & & 1 & & \\
\hline 16. & 3 & 3 & & & & & & & \\
\hline 17. & 2 & 1 & & & & & 6 & & \\
\hline 18. & 2 & 6 & 1 & & & & 2 & & \\
\hline 19. & 10 & 2 & 1 & & & & 1 & & \\
\hline 20. & 13 & 4 & & & & & 1 & & \\
\hline 21. & 3 & 3 & & & & & 1 & & \\
\hline 22. & 4 & 4 & & & & & & & \\
\hline 23. & 2 & 1 & & & & & & & \\
\hline 24. & 1 & 1 & 1 & 3 & & 1 & 3 & & \\
\hline 25. & 4 & & & 3 & & & & & \\
\hline 26. & 5 & & & 1 & & & & & \\
\hline 27. & 9 & 8 & 1 & & & & & & \\
\hline 28. & 5 & 12 & & & & & & & \\
\hline \multirow[t]{2}{*}{29.} & 12 & & & & 1 & 1 & & & \\
\hline & 144 & 78 & 12 & 16 & 6 & 8 & 25 & 1 & 1 \\
\hline
\end{tabular}

Table (2) Projections

\begin{tabular}{|l|l|l|l|}
\hline No. & \multicolumn{3}{|l|}{ projections } \\
\cline { 2 - 4 } & person & place & time \\
\cline { 2 - 4 } &
\end{tabular}




\begin{tabular}{|c|c|c|c|}
\hline 1 & & & \\
\hline 2 & & & \\
\hline 3 & & & 1 \\
\hline 4 & & & \\
\hline 5 & & & \\
\hline 6 & & & \\
\hline 7 & & & \\
\hline 8 & & & \\
\hline 9 & & & \\
\hline 10 & & & 1 \\
\hline 11 & & & \\
\hline 12 & & & \\
\hline 13 & & & \\
\hline 14 & & & \\
\hline 15 & & & 1 \\
\hline 16 & & & \\
\hline 17 & 1 & & \\
\hline 18 & & & \\
\hline 19 & & & \\
\hline 20 & 1 & & \\
\hline 21 & 1 & & \\
\hline 22 & 1 & & \\
\hline 23 & 1 & & \\
\hline 24 & & 1 & \\
\hline 25 & & & 1 \\
\hline 26 & & & \\
\hline 27 & & & 1 \\
\hline 28 & & & \\
\hline 29 & 1 & & \\
\hline & 6 & 1 & 5 \\
\hline
\end{tabular}

Table (3) Context Deixis

No. context 


\begin{tabular}{|c|c|c|c|}
\hline & person & place & time \\
\hline 1 & 1 & 1 & 1 \\
\hline 2 & & 1 & 1 \\
\hline 3 & & 1 & 1 \\
\hline 4 & & 1 & \\
\hline 5 & & 1 & 1 \\
\hline 6 & & & 1 \\
\hline 7 & & 1 & 1 \\
\hline 8 & & 1 & \\
\hline 9 & & & 1 \\
\hline 10 & & & 1 \\
\hline 11 & & & 1 \\
\hline 12 & & & 1 \\
\hline 13 & & & 1 \\
\hline \multicolumn{4}{|l|}{14} \\
\hline \multicolumn{4}{|l|}{15} \\
\hline 16 & & 1 & 1 \\
\hline 17 & & 1 & 1 \\
\hline 18 & & 1 & \\
\hline 19 & & & 1 \\
\hline 20 & & 1 & 1 \\
\hline 21 & & 1 & \\
\hline 22 & & & 1 \\
\hline 23 & & 1 & \\
\hline \multicolumn{4}{|l|}{24} \\
\hline \multicolumn{4}{|l|}{25} \\
\hline 26 & & 1 & \\
\hline 27 & & 1 & \\
\hline 28 & & 1 & \\
\hline \multirow[t]{2}{*}{29} & & 1 & \\
\hline & 1 & 17 & 16 \\
\hline
\end{tabular}

\section{Conclusion}


According to what is selected from Levinson's (1997) deictic centers as the core center of analysis in this research, we find that the place deictic center with its divisions, time deictic centers with its divisions and person deictic center with its divisions are normally found in all the twenty-nine verses of Al-Araff Verse. The first verse contains a general summery and introduction. Moreover, we get to know that there is a complex deictic center in Arabic language that can clearly know and guess by Al_Araff Verse. Also, table (1) shows the good person deictic center as the highest center, which scores 144 point. It is followed by bad person deictic center which scores (78). Whereas, begin deictic center is the lowest one, that scores (6). Moreover, the complex deictic center shows the following results; person (25) which is the highest point of deixis, while place deictic center scores (1) point that equals time deictic center (1) point as well.

\section{References}

[1] [1] Levinson, C. S. (1997). Pragmatics. Cambridge University Press.

[2] [2] Lyons,J. (1977). Semantics. Cambridge University press.

[3] [3] Miftah, Z. M. (2016). Analysis of deixis in the article selected from the jakarta post. Paper presented at the International Languages Toward Global Education System. Retrieved from https://www.researchgate.net

[4] [4] Shazali, M. (2011). Deixis category as favorable syllabus materials- a critical study in sudan practical integrated national english. Theory and Practice in Language Studies, 1(7), 811-820. Retrieved from https://www.researchgate.net

[5] [5] Yang, Y. (2011). A cognitive interpretation of discourse deixis. Theory and Practice in Language Studies, 1(2), 128-135. Retrieved from https://www.researchgate.net

[6] [6] Pratiwi, S. (2018). Person deixis in english translation of summarized shahih al-bukhari hadeath in the book of as-salat. Advances in Language and Literary Studies, 2203-4714, 40-43. Retrieved from. www.alls.aiac.org.ou 